\title{
KELEBIHAN DAN KEKURANGAN LEARNING MANAGEMENT SYSTEM (LMS) MENGGUNKAN PENDEKATAN LITERATURE REVIEW, DAN USER PERSONA
}

\section{Andika Surya Listya Yudhana, Wahyu Andhyka Kusuma}

Universitas Muhammadiyah Malang (UMM) Jawa Timur, Indonesia

Email: listyaandika@webmail.umm.ac.id, kusuma.wahyu.a@gmail.com

INFO ARTIKEL
Diterima
25 Agustus 2021
Direvisi
04 September 2021
Disetujui
15 September 2021

Kata Kunci: user persona; literature review; $L M S$
Keywords: $\quad$ user educational units can find out what are the advantages and persona, Literature disadvantages of LMS so that they can choose which type of Review, LMS LMS will be used or applied.

\section{ABSTRAK}

Semenjak Pandemi Covid-19 Sistem Pendidikan Indonesia telah mengalami perubahan dan perkembangan yang signifikan dari Metode Pembelajaran Luring menjadi Metode Pembelajaran Jarak Jauh atau yang biasa disebut Pembelajaran Daring atau E-Learning yang memanfaatkan Kemajuan Teknologi Komputer, jaringan, dan juga Internet. Dalam penjalanannya E-Learning sering menggunakan Learning Management System (LMS). Maka dari itu artikel ini dibuat dengan tujuan agar para pembaca dan pelaku pendidikan di Indonesia mengenal kelebihan dan kekurangan dari LMS dalam Pembelajran Daring menggunakan metode Literature Review, dan User Persona. Maka dari itu diharapkan dengan adanya penelitian ini satuan pendidikan dapat mengetahui apa saja kelebihan dan kekurangan dari $L M S$ sehingga dapat memilih jenis $L M S$ mana yang akan digunakan atau diterapkan.

\section{ABSTRACT}

Since the Covid-19 Pandemic, the Indonesian Education System has undergone significant changes and developments from the Offline Learning Method to the Distance Learning Method or commonly called Online Learning or E-Learning that utilizes Advances in Computer Technology, networks, and the Internet. In its implementation, E-Learning often uses a Learning Management System (LMS). Therefore, this article was created with the aim that readers and education actors in Indonesia know the advantages and disadvantages of LMS in Online Learning using the Literature Review method, and User Persona. Therefore, it is hoped that with this research,

$\begin{array}{ll}\text { How to cite: } & \text { Yudhana, A. S. L., Kusuma, W. A. (2021) Kelebihan dan Kekurangan Pembelajaran Jarak Jauh Atau } \\ & \text { E-Learning dan Learning Management System (LMS) Menggunkan Pendekatan Literature Review, } \\ & \text { dan User Persona. Jurnal Syntax Admiration 2(9). https://doi.org/10.46799/jsa.v2i9.303 } \\ \text { E-ISSN: } & 2722-5356 \\ \text { Published by: } & \text { Ridwan Institute }\end{array}$




\section{Pendahuluan}

Ketika krisis kesehatan COVID-19 mulai menyebar, Sistem Pendidikan Indonesia menggunakan sistem baru, sistem pembelajaran jarak jauh, untuk mengajar di kelas (Kristanto, 2020). Hal ini dilakukan dengan tujuan pencegahan penyebaran COVID-19 agar tidak lebih luas lagi. Oleh karena itu, perubahan kebijakan di bidang pendidikan Indonesia diubah sedemikian rupa. Kebijakan ini diresmian dalam bentuk surat. Pemberitahuan nomor 4 Tahun 2020 (Terkait pelaksanaaan kebijakan pendidikan darurat penyebaran penyakit virus Corona (COVID-19) tanggal 24 Maret 2020 merekomendasikan agar proses belajar mengajar dirumah dilanjutkan melalui pembelajaran online. Pembelajaran online atau Pembelajaran Jarak Jauh (PJJ) atau ELearning adalah pembelajaran berbasis teknologi, yang menggunakan teknologi untuk menyelenggarakan program pendidikan, dan pelatihan (Alfina, 2020).

Tidak bisa dipungkiri lagi bahwa teknolgi digital merupakan sistem pendidikan paling berpengaruh di dunia saat ini (Wardhana et al., 2020). Dengan menggunakan teknologi digital, dalam proses pembelajaran siswa dan guru dapat berada di tempat yang berbeda atau tidak di lokasi yang sama. Meskipun guru dan siswa terpisah, harus ada komunikasi diantara mereka. Solusi terbaik dalam hal ini adalah menggunakan Learning Management System (LMS). LMS adalah sistem untuk melihat, melacak, melaporkan, dan mengatur konten pembelajaran, kinerja siswa, dan interaksi siswa (Rizal \& Walidain, 2019). Namun, para pelaku pendidikan di Indonesia belum terlalu mengenal apa itu E-Learning (Pembelajaran Online), serta kelebihan dan kekurangannya. Maka dari itu artikel ini dibuat dengan tujuan agar para pembaca dan pelaku pendidikan di Indonesia mengenal kelebihan dan kekurangan dari LMS. Adapun artikel ini dibuat dengan mengimplementasikan metode Literature Review, dan User Persona.

Penelitian yang dilakukan oleh (Alfina, 2020). "Penerapan Lms-Google Classroom Dalam Pembelajaran Daring Selama Pandemi Covid-19”, penelitian yang dilakukan (Iswara et al., 2019) berjudul "Kemampuan Koneksi Matematis siswa melalui Model Pembelajaran Preprospec Menggunakan Edmodo", dan penelitian yang dilakukan oleh (Rizal \& Walidain, 2019) berjudul "Pembuatan media pembelajaran Elearning berbasis moodle pada matakuliah pengantar aplikasi komputer Universitas Serambi Mekkah" dimanfaatkan oleh peniliti sebagai rujukan dalam melakukan penelitian. Proses pengujian pada penelitian ini menggunaka metode Literature Review namun terdapat beberapa hal yang membedakan penilitan yang dilakukan dengan penilitian yang dijadika rujukan. Perbedaan yang dimaksud adalah penjelasan kelebihan dan kelemahan dari setiap Learning Managemen System yang digunakan dalam artikel rujukan serta penggunaan User Persona dalam mengetahui kekurangan dari LMS edm.

\section{Metode Penelitian}

1. Literature Review

Literature Review berarti tidak hanya membaca literatur, tetapi juga evaluasi yang mendalam dan kritis terhadap penelitian sebelumnya tentang subjek tersebut. 
Literature Review meliputi komentar, abstrak, dan pemikiran penulis tentang beberapa sumber perpustakaan (bisa berupa artikel, buku, slide, informasi dari internet,dll).

Penulusuran pencarian literatur dengan mencari literatur di Google Search dan Google Scholar menggunakan kata kunci. Dokumen literatur yang dipilih adalah artikel dan terbitan berkala dari Tahun 2019 hingga Tahun 2021 yang teks lengkapnya dalam format PDF dan bahasa Indonesia atau bahasa Inggris. Artikel yang memenuhi kriteria akan digunakan untuk analsis lebih lanjut. Tabel berikut mencantumkan kritertia inklusi literasi yang akan review (Wijayanti et al., 2017):

Tabel 1

Kriteria Inklusi Literasi

\begin{tabular}{cc}
\hline Kriteria & Inklusi \\
\hline Jangka Waktu & $\begin{array}{c}\text { Terbitan bekala dari Tahun } \\
\text { 2019 hingga 2021 }\end{array}$ \\
\hline Subjek & $\begin{array}{c}\text { Pembelajaran Jarak Jauh dan } \\
\text { LMS }\end{array}$ \\
\hline Bahasa & $\begin{array}{c}\text { Bahasa Indonesia dan Bahasa } \\
\text { Inggris }\end{array}$ \\
\hline Jenis Jurnal & Artikel Penilitan dalam format \\
& PDF \\
\hline
\end{tabular}

\section{User Persona}

Dalam jurnal ini Metode User Persona hanya digunakan dalam mengetahui apa saja kelemahan dari LMS berbasis Moodle (Wicaksana, 2020). Adapun alur penelitian yang dilakukan sebagai berikut:

1. Penentuan Narasumber atau Stakeholder

Tahap ini dilakukan dengan menentukan perwakilan dari stakeholder dari aplikasi $L M S$ berbasis moodle.

\section{Wawancara}

Tahap wawancara dilakukan dengan melakukan video call menggunakan media Google Meet dan Zoom. Tujuan dilakukannya wawancara adalah untuk menggali kebutuhan pengguna/stakeholder, dan keluhan/ masalah apa saja yang dihadapi oleh stakeholder selama menggunakan LMS berbasi Moode. Adapun pertanyaan yang diajukan kepada setiap narasumber merupakan pertanyaan mengenai kebutuhan dan kekurangan sistem dan fitur $L M S$ berbasis moodle yang diterapkan dalam PJJ Prodi Informatika Universias Muhammadiyah Malang.

3. Pembuatan User Persona

Pembuatan User Persona bertujuan untuk mengklarifikasikan pengguna berserta masalah dan kebutuhan dari masing-masing pengguna.

4. Pembuatan Flowchart

Story Board berfungsi sebagai rangkuman dari User persona yang sudah diklarifikasikan berdasarkan jabatan atau peran pengguna. 


\section{Hasil dan Pembahasan}

\section{A. E-Learning}

\section{Definisi E-Learning}

Pembelajaran online atau bisa disebut E-Learning dapat diartikan sebagai berikut (Alfina, 2020):

1) E-Learning merupakan pembelajaran berbasis teknologi, dimana teknologi digunakan untuk menyampaikan program pembelajaran dan pelatihan;

2) E-Learning diartikan sebagai pembelajaran yang berorientasi pada sistem pengiriman materi berbasis elektronik;

3) E-Learning diartikan sebagai pembelajaran yang difasilitasi dengan penggunaan alat dan koten digital yang melibatkan beberapa bentuk interaktivitas yang termasuk di dalamnya interaksi online antara dosen maupun mahasiswa atau antara mahasiswa dengan rekan mahasiswa lainnya;

4) E-Learning diartikan sebagai pembelajaran yang berorientasi pada paradigma pendidikan, yang masa teknologi, informasi, dan komunikasi digunakan untuk mendukung siswa maupun mahasiswa dalam meningkatkan kualitas pembelajaran mereka (Elyas, 2018).

\section{Karakteristik E-Learning}

Dari beberapa definisi E-Learning diatas dapat disimpulkan, E-Learning merupakan suatu sistem atau konsep pendidikan yang menggunakan teknologi informasi dalam proses pengajarannya (Latip, 2020). Karakteristik E-Learning Inggriyani (Inggriyani et al., 2019) antara lain:

1) Penggunaan teknologi elektronik untuk mempromosikan, dan mempercepat penggunaan informasi;

2) Penggunan media komputer (seperti jaringan komputer atau media digital).

3) Penggunaan bahan belajar mandiri.

4) Bahan ajar yang disimpan di komputer atau media lainnya.

5) Media mudah diakses untuk mengukur kinerja akademik.

6) Dapat memberikan informasi kepada bagian administrasi.

Sementara itu Mustaka Sagita dan Kharunnisa berpendapat bahwa ELearning memiliki beberapa karakteristik, yaitu (Sagita \& Nisa, 2019):

1) Memanfaatkan layanan teknologi elektronik.

2) Penggunaan komputer (media digital dan jaringan komputer).

3) Menggunakan bahan ajar yang bersifar mandiri kemudian disimpan di komputer sehingga dapat diakses oleh dosen dan mahasiswa kapan saja dan dimana saja.

4) Anda dapat memeriksa penggunaan rencana studi, kurikulum, hasil studi, dan masalah manajemen pendidikan di komputer Anda kapan saja.

\section{Manfaat Penggunaan E-Learning}

E-Learning dapat meciptakan suasana baru untuk pengembangan berbagai kesempatan belajar. Penggunaan E-Learning yang benar dapat memaksimalkan 
hasil belajar. Adapun manfaat dari penggunaan E-Learning berdasarkan karakterisik E-Learning yang ditulis diatas:

1) Flesksibilitas dalam waktu dan tempat

2) Siswa atau Mahasiswa bebas memutuskan kapan memulai, kapan haus menyelesaikan dan bagian mana dari modul yang akan dipelajari terlebih dahulu. Jika anda menemui kesulitan, Anda bisa melakukannya lagi sampai Anda merasa bisa mengerti.

3) Dapat menghemat biaya, termasuk biaya perjalanan ke lokasi belajar, dan akomodasi selama masa studi, biaya administrasi, fasilitas fisik, dan ruang kelas.

4) Jika siswa/mahasiswa belum memahami atau memahami suatu modul, mereka dapat mengulang modul tersebut kembali hingga mereka memahaminya.

5) Proses administrasi yang otomatis

\section{Kekurangan E-Learning}

Pemanfaatan internet untuk pembelajaran atau e-learning juga tidak terlepas dari berbagai kekurangan, antara lain (Sagita \& Nisa, 2019) :

1) Kurangnya interaksi antara guru/dosen dan siswa/mahasiswa, maupun siswa/mahasiswa dengan siswa/mahasiswa;

2) Mengabaikan aspek akademik dan aspek sosial;

3) Proses belajar mengajar cenderung ke arah pelatihan dari pada pendidikan;

4) Berubahnya peran guru dari yang semula menguasai teknik pembelajaran konvensional, kini dituntut mengetahui teknik pembelajaran menggunakan ICT;

5) Siswa/mahasiswa yang tidak memiliki motivasi belajar cenderung gagal;

6) Tidak semua daerah (terutama di Indonesia) tersedia jaringan Internet;

7) Kurang tenaga kerja pendidikan yang mengetahui dan memiliki keterampilan internet;

\section{B. Penggunaan Gambar}

\section{1) Definisi Learning Management System (LMS)}

Faktor penting dalam mengimplementasikan dan pelaksanaan pembeljaran online adalah Learning Management System (LMS). LMS adalah sistem yang menangani manjajemen pembelajaran (seperti identifikasi, penilaian, pelacakan kemajuan, dan pencatatan tugas umum seperti tugas pribadi) (Rizal \& Walidain, 2019). LMS bertujuan untuk membantu siswa dan pembelajaran dengan mudah menemukan sumber informasi pendidikan. Dengan bantuan $L M S$, dosen dapat melacak siswa/mahasiswa, dan mahasiswa yang terdaftar dalam mata kuliah, mendistribusikan materi pembelajaran, dan membuat platform untuk berdiskusi tentang ide, tugas, dan menilai tugas, memberikan umpan balik yang baik dan memberikan nilai kepada siswa/mahasiswa. Singkatnya, $L M S$ menyediakan tempat bagi para pendidik (guru dan dosen) untuk memantau dan mempromosikan kemajuan siswa/mahasiswa. Di sisi lain, siswa/mahasiswa diuntungkan karena mereka diberikan waktu dan ruang belajar yang sesuai dengan kemampuan 
pemahaman mereka. LMS juga memungkinkan pendidik untuk menciptakan lingkungan belajar online dimana siswa dapat berpartisipasi dalam berbagai kegiatan yang berhubungan dengan pembelajaran (Alfina, 2020).

\section{2) Ciri-Ciri LMS}

Ciri-ciri Learning Management System menurut Jaqueline sebagai berikut :

1) Menggunakan "self-service", dan "self-guided";

2) Kumpulkan, dan sampaikan konten atau bahan ajar dengan cepat;

3) Menggabungkan program pelatihan pada platform web;

4) Mendukung suatu portabilitas dan suatu standar personalisasi isi dan juga penggunaan kembali pengetahuan;

\section{3) Jenis-Jenis LMS}

Beberapa jenis LMS yang dapat digunakan untuk E-Learning selama pandemi COVID-19, meliputi

\section{Edmodo}

Edmodo adalah jerjaring sosial pendidikan yang diyakini menyediakan cara belajar yang aman dan nyaman bagi siswa/mahasiswa dan guru/dosen. Guru/dosen dapat membuat nilai, tugas, kuis, parameter, dan memberikan saran untuk diskusi siswa/mahaiswa (Iswara et al., 2019). Edmodo memungkin mengevaluasi pembelajaran siswa/mahasiswa berdalasakan elemen atau fitur yang disediakan Edmodo (Alfina, 2020).

Keunggulan fitur edmodo menurut Yuni Fitriani adalah (Fitriani, 2020):

a) Fitur kolaborasi antara pengguna misalnya dosen yang satu dengan dosen yang lainnya.

b) Catatan pada Edmodo memumingkan siswa/mahasiswa mengajukan pertanyaan singkat dan berbagai status seperti di media sosial.

c) Penyimpanan yang terorganisir untuk dokumen dengan cepat dan aman.

d) Kemampuan untuk menciptakan kelompok siswa/mahasiswa yang lebih kecil dalam kelas.

Sedangkan menurut Ranggamurti (Iswara et al., 2019) kelebihan dari Edmodo, meliputi:

a) Mudah untuk mengirim berkas, gambar, video, dan link.

b) Mengirim pesan individu ke pengajar.

c) Membuat grup untuk diskusi tersendiri menurut kelas atau topik tertentu.

d) Lingkungan yang aman untuk siswa baru.

e) Pesan dirancang untuk lebih mudah dipahami dan tidak dibatasi oleh jumlah karakter.

Dari kelebihan-kelebihan yang dimilki Edmodo, Edmodo juga memiliki kekurangan, kekurangan fitur Edmodo meliputi (Iswara et al., 2019):

a) Gangguan pada koneksi internet dapt mempengaruhi website berjalan lebih lambat

b) Siswa dibatasi aksesnya untuk keluar, karena hanya terbatas di kelas tersebut

c) Masih dalam versi pengembangan dan belum sempurna seutuhnya 
d) Tidak adanya fitur chat seperti yang terdapat di media sosial pada umumnya

\section{Google Classroom}

Platofrm ini adalah platform yang dirancang secara gratis untuk siswa, mahasiswa, guru maupun dosen yang dapat digunakan untuk mengunduh bahan bacaan, baik itu pembelajaran tatap muka ataupun pembelajaran online (ELearning) yang dibuat oleh Google (Alfina, 2020). Pada tulisannya Ommi Alfina menyatakan ada beberapa kelebihan yang dimiliki Google Classrom, yaitu (Alfina, 2020):

a) Memiliki ruang penyimpanan yang terintegrasi dengan produk Google lainnya, seperti Google Drive serta email, dan Google Mail (GMAIL);

b) Platform ini dapat menggabungkan beberapa kelas yang berbeda dalam satu forum;

c) Pengguna pada platform ini juga dapt berbagi maupun mengintegrasikan video, file, PDF, maupun gambar, serta menggabungkan URL perpustakaan virtual maupun sumber daya eksternal lainnya.

Sedangkan menurut Yuni Fitriani keunggulan atau kelebihan dari Google Classroom meliputi (Fitriani, 2020):

a) Gratis dan mudah.

b) Integrasi sistem Google menggabungkan YouTube, Gmail Drive, dan layanan lain milik google dalam satu akun.

c) Kemudahan dalam penugasa. Pengguna yang berperan sebagai pengajar dapat dengan mudah memantau pekerjaan murid atau tugas yang telah mereka selesaikan, siapa saja yang sudah ataupun belum mengumpulkan tugas.

d) Fitur Assigment. Fitur ini memudahkan pengajar dalam membuat quiz dan semacamnya seperti menggunakan Google Form.

e) Form pertanyaan. Pada fitur ini siswa/mahasiswa dapat bertanya tentang materi apa yang belum pahami dalam pembelajaran.

Adapun kelemahan yang dimiliki Google Classroom, menurut Nurhusna kelemahan yang dimiliki Google Classroom terdiri dari (Nurhusna, 2020):

a) Kesulitan melakukan diskusi secara virtual, hal ini dikarenakan belum tersedia nya fitur video dalam Google Classroom sehingga menjadi hambatan bagi pembelajaran yang membutuhkan diskusi secara langsung.

b) Kesulitan mengedit hasil ujian, salah satu aturan dari Google Classroom adalah guru/dosen dapat mengatur ketika membuat pertanyaan, dan siswa/mahasiswa tidak dapat mengedit jawaban. Hal ini menyebabkan ketersimpangan pendapat dimana menurut guru/dosen hal tersebut menguntungkan supaya siswa/mahasiswa tidak memiliki waktu untuk menyontek. Sedangkan menurut siswa/mahasiswa hal ini merugikan dikarenakan mereka tidak dapat mengedit jawaban setelah dikirim (Harefa \& Sumiyati, 2020). 


\section{Moodle}

Kelebihan yang dimiliki moodle yaitu (Nurhusna, 2020):

a) Semua orang dapat mengunduh software Moodle secara gratis di situs resminya;

b) Bersifat Open Source, sehingga pengguna terutama pengajar dapat merancang sesuai dengan kebutuhan proses pembelajaran;

c) Proses instalasi yang mudah;

d) Memiliki fitur kuis, tugas, dan pemberian nilai yang dapat diatur sesuai kebutuhan;

e) Memiliki daya tampung peserta didik yang banyak;

f) Mendukung banyak type file yang dapat digunakan dalam proses pembelajaran;

g) Dapat memuat beberapa mata pelajaran atau mata kuliah;

h) Dapat memilih bahasa sesuai kebutuhan;

i) Dapat mengganti tampilan situ dikarenakan mmiliki fitur/menu ganti themes.

Adapun kelemahan dari Moodle itu sendiri berdasarkan hasil penelitian yang kami lakukan menggunakan metode pendekatan User Persona dijelaskan sebagai berikut:

1. Penentuan Stakeholder atau narasumber

Adapun stakeholder atau narasumber dalam penelitian ini adalah

- Mahasiswa Prodi Informatika Universitas Muhammadiyah Malang;

- Dosen Prodi Informatika Universitas Muhammadiyah Malang;

- Tata Usaha Prodi Informatika Universitas Muhammadiyah Malang;

2. Wawancara

Dari wawancara yang dilkakukan dengan stakeholder didapati beberapa permasalah dan kekurangan dari LMS yang dipakai oleh Prodi Informatika Univrersitas Muhammadiyah Malang yang akan dicantumkan di user persona (Muhammad et al., 2020).

3. Pembuatan User Persona

Dari wawancara yang telah dilakukan dengan para stakeholder dibuatlah user persona dari masing-masing stakeholder/narasumber sebagai berikut: 
Kelebihan dan Kekurangan Learning Management System (LMS) Menggunkan Pendekatan Literature Review, dan User Persona

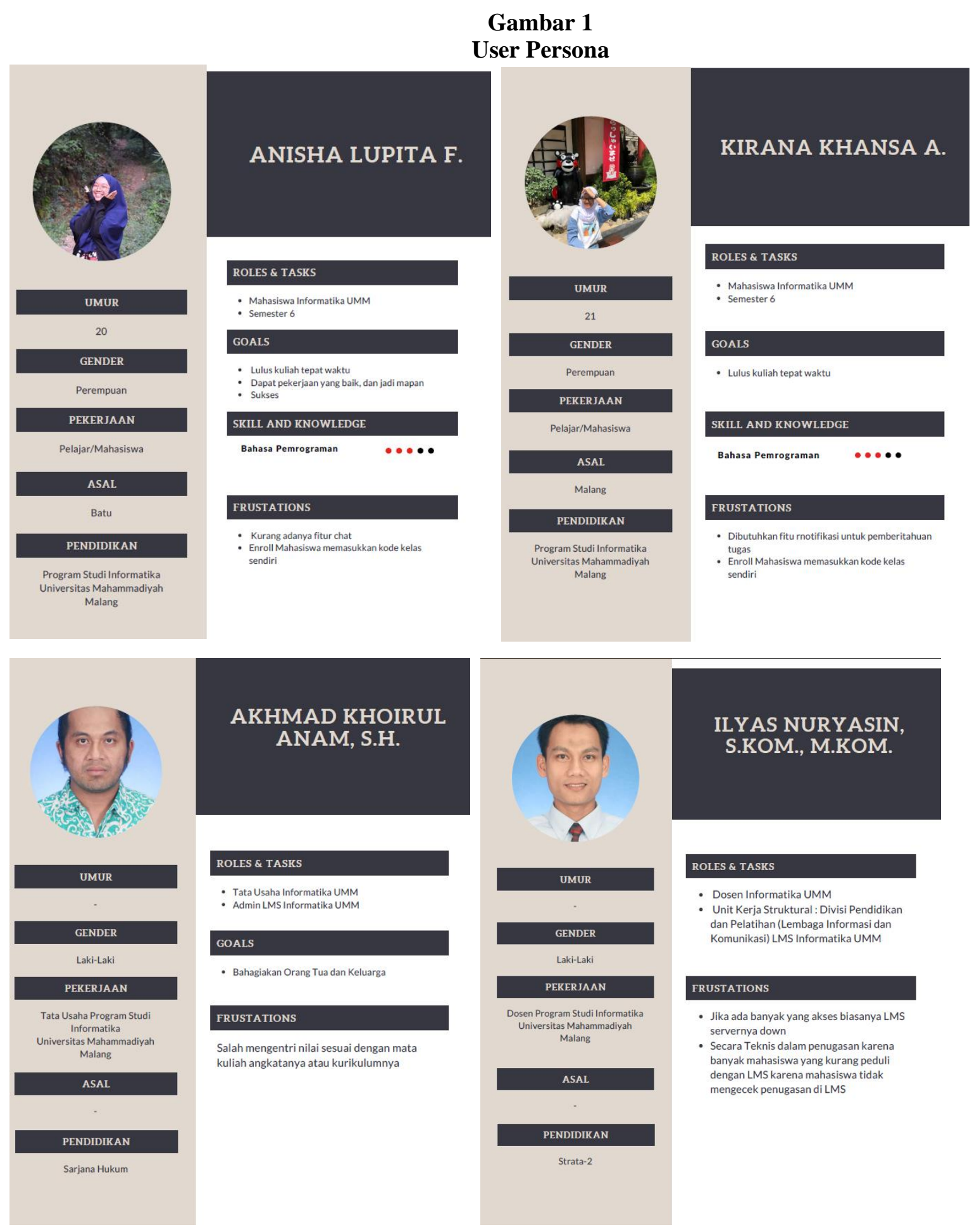




\section{Pembuatan Flowchart}

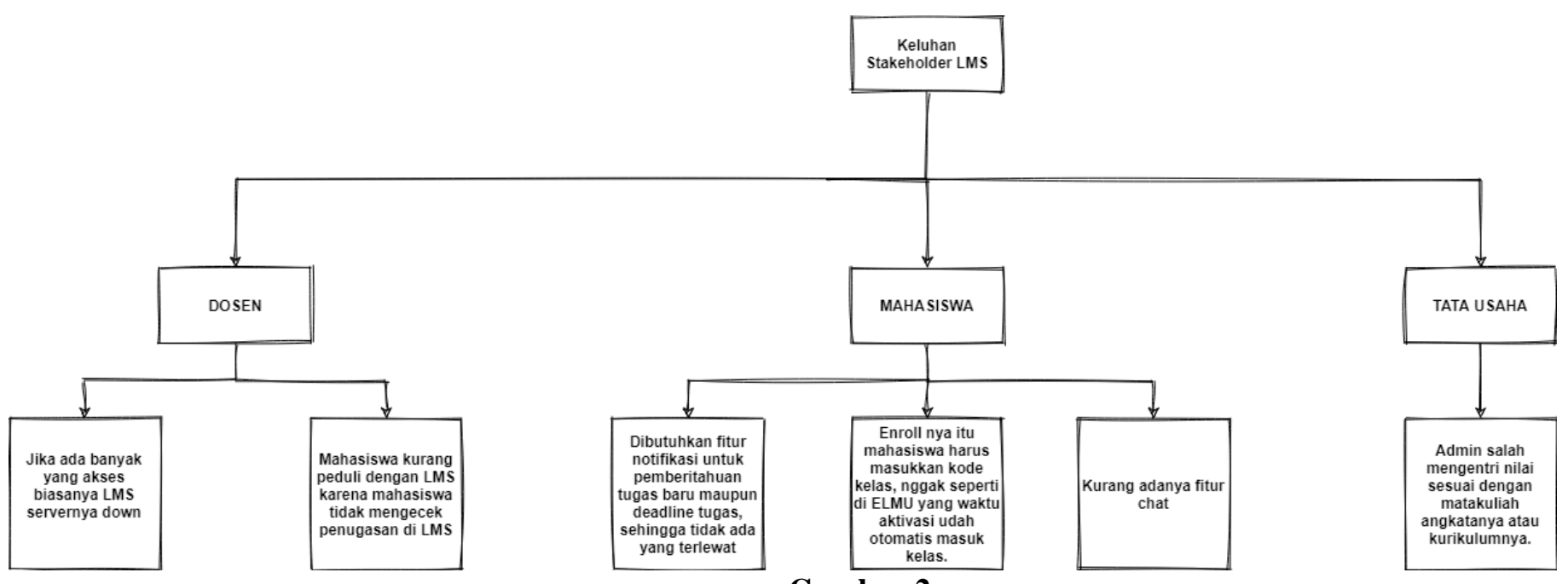

Flowchart keluhan stakeholder LMS UMM

\section{Kesimpulan}

Berdasarakan pemaparan pembahasan diatas dapat disimpulkan bahwa, pembelajaran jarak jauh atau E-Learning merupakan kegiatan pembeljaran yang dimana kegiatannya memanfaatkan internet, kemajuan teknologi informasi, dan kemajuan komunikasi saat ini. Salah satu unsur penting dari pelaksanaan pelaksanaan E-Learining yaitu pemanfaatan Learning Management System (LMS). Learning Management System merupakan sebuah system yang digunakan untuk mengelola, dan mengimplementasikan kegiatan pembelajaran jarak jauh pada beberapa bidang antara lain nilai, pemberian materi, pemberian tugas, dan memonitor peserta didik. Adapun jenis jenis $L M S$ yang ada seperti Edmodo, Google Classroom, dan Moodle. Dengan dilakukannya penelitian ini bisa diketahui apa saja kelebihan dan kekurangan dari masing-masing jenis LMS yang ada. Maka dari itu diharapkan dengan adanya penelitian ini satuan pendidikan dapat mengetahui apa saja kelebihan dan kekurangan dari $L M S$ sehingga dapat memilih jenis LMS mana yang akan digunakan atau diterapkan. 


\section{BIBLIOGRAFI}

Alfina, O. (2020). Penerapan Lms-Google Classroom Dalam Pembelajaran Daring Selama Pandemi Covid-19. Majalah Ilmiah Methoda, 10 (1), 38-46. https://doi.org/10.46880/methoda.v10i1.537. Google Scholar

Elyas, A. H. (2018). Penggunaan model pembelajaran e-learning dalam meningkatkan kualitas pembelajaran. Warta Dharmawangsa, 56. Google Scholar

Fitriani, Y. (2020). Analisa Pemanfaatan Learning Management System (LMS) Sebagai Media Pembelajaran Online Selama Pandemi COVID-19. Journal of Information System, Informatics and Computing, 4(2), 1-8. Google Scholar

Harefa, N., \& Sumiyati, S. (2020). Persepsi Siswa terhadap Google Classroom sebagai LMS pada masa Pandemi Covid-19. Science Education and Application Journal, 2 (2), 88-100. Google Scholar

Inggriyani, F., Fazriyah, N., \& Purbasari, A. (2019). Penggunaan E-learning Berbasis Moodle bagi KKG Sekolah Dasar di Kecamatan Lengkong Kota Bandung. Jurnal Solma, 8 (2), 268. Google Scholar

Iswara, R., Adhi, D. N. R. N., \& Cahyono, N. A. (2019). Kemampuan Koneksi Matematis siswa melalui Model Pembelajaran Preprospec Menggunakan Edmodo. Prosiding Seminar Nasional Pascasarjana (Prosnampas), 2 (1), 274-277. Google Scholar

Kristanto, Y. D. (2020). Covid-19, Merdeka Belajar, dan Pembelajaran Jarak Jauh. Google Scholar

Latip, A. (2020). Peran literasi teknologi informasi dan komunikasi pada pembelajaran jarak jauh di masa pandemi Covid-19. EduTeach: Jurnal Edukasi Dan Teknologi Pembelajaran, 1 (2), 108-116. Google Scholar

Muhammad, H., Murtinugraha, R. E., \& Musalamah, S. (2020). Pengembangan media pembelajaran e-learning berbasis moodle pada mata kuliah metodologi penelitian. Jurnal Pensil: Pendidikan Teknik Sipil, 9 (1), 54-60. Google Scholar

Nurhusna, N. (2020). Google Classroom sebagai Media Pembelajaran pada Mata Kuliah Teks Bahasa Indonesia. Seminar Nasional Pendidikan Bahasa Dan Sastra, 1 (1), 52-57. Google Scholar

Rizal, S., \& Walidain, B. (2019). Pembuatan media pembelajaran E-learning berbasis moodle pada matakuliah pengantar aplikasi komputer Universitas Serambi Mekkah. Jurnal Ilmiah Didaktika: Media Ilmiah Pendidikan Dan Pengajaran, 19 (2), 178-192. Google Scholar 
Sagita, M., \& Nisa, K. (2019). Pemanfaatan E-Learning Bagi Para Pendidik Di Era Digital 4.0. Jurnal Sosial Humaniora Sigli, 2 (2), 35-41. Google Scholar

Wardhana, A. C., Segara, A. J. T., Adhinata, F. D., \& Rakhmadani, D. P. (2020). Pelatihan Pembelajaran Jarak Jauh Menggunakan Learning Management System Berbasis Moodle Untuk Guru Di SMK Maarif NU 2 Ajibarang. Logista-Jurnal Ilmiah Pengabdian Kepada Masyarakat, 4 (2), 231-237. Google Scholar

Wicaksana, E. (2020). Efektifitas Pembelajaran Menggunakan Moodle Terhadap Motivasi Dan Minat Bakat Peserta Didik Di Tengah Pandemi Covid-19. EduTeach: Jurnal Edukasi Dan Teknologi Pembelajaran, 1 (2), 117-124. Google Scholar

Wijayanti, W., Maharta, N., \& Suana, W. (2017). Pengembangan perangkat blended learning berbasis learning management system pada materi listrik dinamis. Jurnal Ilmiah Pendidikan Fisika Al-Biruni, 6 (1), 1-12. Google Scholar

\section{Copyright holder:}

Andika Surya Listya Yudhana, Wahyu Andhyka Kusuma (2021)

First publication right:

Jurnal Syntax Admiration

This article is licensed under:

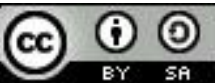

